Accepted Manuscript (AM) of King, R., Castaldo, A. and Vullnetari, J. (2011) Gendered relations and filial duties along the Greek-Albanian remittance corridor. Economic Geography 87(4): 393419 [DOI: 10.1111/j.1944-8287.2011.01128.x][accepted 20 March 2011; published November 2011].

\title{
Gendered Relations and Filial Duties Along the Greek- Albanian Remittance Corridor
}

\author{
Russell King, Adriana Castaldo and Julie Vullnetari
}

\begin{abstract}
Remittances stand at the heart of the migration-development debate. However, they are overwhelmingly considered in financial and economic terms, neglecting important dimensions such as gender and patriarchal family structures. This paper contributes to rectifying this oversight by analyzing remittance flows resulting from Albanian migration to neighboring Greece. We draw on a detailed questionnaire survey with 350 remittancerecipient households in rural south-east Albania and 45 in-depth interviews with a selection of these respondents and with remitters living in the Greek city of Thessaloniki. We find that gender is interlinked with generation and life-course stages within the context of Albanian patriarchal norms; and that remittances are shaped accordingly. Whilst remitting to older parents is a filial duty for unmarried sons, upon marriage only the youngest son has this responsibility - other sons send small amounts as tokens of respect and love. Sending remittances is overwhelmingly seen as a 'male thing'. Single young women rarely migrate for work on their own abroad. Meanwhile any remittances sent by married daughters to their parents are considered 'unofficial', referred to as 'coffee money'. Within nuclear households, some increased power-sharing among husband remitters and wife-recipients takes place. However, the latter are far from passive recipients, as they struggle to combine caring for children and the elderly with farm work or day laboring. We conclude that a deeper understanding of how remittances are gendered can be gained by placing their analysis within the migratory and socio-cultural context into which they are embedded.
\end{abstract}

Key words: gender, patriarchy, remittances, Albania, migration

[The Version of Record of this manuscript has been published and is available in Economic Geography; November 2011; DOI: 10.1111/j.1944-8287.2011.01128.x]. 
Accepted Manuscript (AM) of King, R., Castaldo, A. and Vullnetari, J. (2011) Gendered relations and filial duties along the Greek-Albanian remittance corridor. Economic Geography 87(4): 393419 [DOI: 10.1111/j.1944-8287.2011.01128.x][accepted 20 March 2011; published November 2011].

In the fast-growing array of studies on remittances and their contribution to development, a gendered perspective is usually lacking. We seek to rectify this oversight by analyzing migration from Albania to Greece, and the remittances flowing in the opposite direction. We select this 'migration and remittance corridor' because of the scale of Albanian migration to Greece (roughly one in five of the Albanian population now lives there) and its concentration in time - the past twenty years.

How are remittances gendered? In the literature on this theme, the question is generally reduced to a consideration of whether women are 'better' remitters than men - in terms of amounts sent, regularity of sending, and use of the money. Using the terminology of Lucas and Stark (1985), women are thought to be more likely to act out of altruism towards their family members than self-interest. However, in a patriarchal social and family environment such as Albania, asking whether women remit more, or 'better' than men, his simply not the right question since, on the whole, women are not 'allowed' to remit. In Albania (and, we surmise, other patriarchal societies), the relevant research questions on gendering remittances are about context and effects, namely:

1. How do Albanian norms of gender relations and patriarchy shape migration and remittance patterns?

2. How do remittances - both sending and receiving them - reshape relations of gender and patriarchy, both within Albania and amongst Albanian migrant households abroad?

We deploy two datasets to respond to these questions: a questionnaire survey of 350 remittance-receiving households in rural south-east Albania, and 45 in-depth interviews with selected households from this survey, and with migrants from this area living and working in the Greek city of Thessaloniki. Before presenting our analyses of these data within the framework of the above two research questions, we need to briefly, but incisively, review the literature and theory on gendering remittances, and introduce the Albanian context of migration patterns and gender relations. 
Accepted Manuscript (AM) of King, R., Castaldo, A. and Vullnetari, J. (2011) Gendered relations and filial duties along the Greek-Albanian remittance corridor. Economic Geography 87(4): 393419 [DOI: 10.1111/j.1944-8287.2011.01128.x][accepted 20 March 2011; published November 2011].

\section{Gendering Remittances: The Story So Far}

In recent years, research on the linkages between migration and development has grown rapidly, ${ }^{1}$ alongside an increasing policy focus on migration as a route out of poverty. The UNDP's Human Development Report for 2009 was a study of overcoming barriers to human mobility in order to release the potential of migrants to improve their livelihoods and contribute to development, both in the destination and home-country settings (UNDP 2009). At the heart of the migration-development debate stand remittances - money that migrants earn abroad and send to their families back home. ${ }^{2}$ Such capital transfers, which surpassed $\$ 440$ billion in 2010, including $\$ 325$ billion to developing countries (World Bank 2011: x), are claimed to have a major positive impact on the economic development of countries of origin as well as a direct effect on poverty reduction because they flow directly to low-income households. Not for nothing have remittances become the 'new development mantra' of the past decade or more (Kapur 2004), although more critical voices are not lacking (Carling 2008; de Haas 2005; Kunz 2008).

The Albanian case is particularly emblematic because of the sudden importance that remittances took on in the early 1990s in shoring up the national economy and in sustaining livelihoods, especially in rural areas. Remittances proved critical in transcending the chaos that accompanied the post-communist transition from what had been Eastern Europe's most hardline and isolated state-socialist regime. For nearly two decades now, Albania has been near the top of global rankings of the importance of remittances in national accounts and as per capita inflows (de Zwager et al. 2005).

Despite the progressive mainstreaming of gender into human geography, migration and development studies, this aspect is conspicuously absent in the literature on remittances. To cite one specific example, gender does not feature in the list of 'core questions' in Carling's (2008) otherwise insightful interrogation of the remittances debate. Some authors have at least acknowledged the missing dimension of gender whilst at the same time playing into the stereotype that

\footnotetext{
${ }^{1}$ For accessible and authoritative overviews see Castles and Delgado Wise (2008), Hammar et al. (1997), Van Hear and Nyberg Sørensen (2003).

2 Remittances can also be generated by internal migration. Internal remittances are an understudied part of the development literature, but are not directly relevant to our analysis in this paper.
} 
women are 'better' remitters than men. Typical of this genre is the following statement by Nyberg Sørensen (2005: 3):

... it is generally assumed that women... send back home a greater share of their earnings in remittances than men and also tend to be better savers... [W] hen in control of remittances, [women] are believed to channel overseas financial transfers into better health, nutrition and education for the entire family... However, gaps remain in our understanding of the gender dimensions of remittances... Only very little research has been done on gender differences in migrants' remittance practices...

This situation is all the more poignant since research on both development and migration as single overarching themes increasingly engages with gender as a fundamental dynamic and crucial analytical tool which structures social life and individual behavior.

This is schematically illustrated in Figure 1 which maps the relationships between migration, remittances, development and gender in terms of pairings of interlinked processes and literatures. The arrows indicate the main direction of causality, either predominantly one-way or recursive. Moving round the diagram, we note the following grosso modo relationships. First, there is abundant evidence, mainly empirical but with clear theoretical and policy implications, that migration produces remittances. By and large, the causal relationship is one-way, but there is also a potential feedback loop in the sense that remittances can also, by their demonstration effect, stimulate new migration. Second, the causal link from remittances to development is clear with respect to direction but less so with regard to outcome. Glick Schiller and Faist (2009) argue that remittances can lead to a dangerous dependency on this source of foreign capital, and can increase social and spatial inequality within the migrant-sending country. ${ }^{3}$ In these

\footnotetext{
3 Evidence on this for Albania has been considered by Azzarri and Carletto (2009), Lerch and Wanner (2005), and Zezza et al. (2005). The last-named showed that, at least in the early years of emigration from Albania (the 1990s), most poverty-stricken households in the rural north were too poor to emigrate; hence remittances, which went mainly to southern and coastal districts, increased regional inequality. Lerch and Wanner confirmed this regional contrast but also pointed out that within high-emigration areas, remittances reduced inequality. After 2000, however, northern households participated more in migration abroad, often combined with a wider family survival
} 
Accepted Manuscript (AM) of King, R., Castaldo, A. and Vullnetari, J. (2011) Gendered relations and filial duties along the Greek-Albanian remittance corridor. Economic Geography 87(4): 393419 [DOI: 10.1111/j.1944-8287.2011.01128.x][accepted 20 March 2011; published November 2011].

important debates on remittances, development and inequality, the gender dimension is rarely highlighted and often not even acknowledged.

When we come to examine gender's bilateral links first with migration and then with development, we see a much more active, synergetic relationship in the respective literatures. 'Gendering migration' has been an increasingly powerful analytical lens since the landmark writings of feminist migration scholars in the 1980s (Morokvasic 1984; Phizacklea 1983), and geographers have played a prominent role in taking these debates forward (see, inter alia, Boyle 2002; Kofman 2004; Silvey 2004). Likewise 'gendering development' has an established tradition of academic and policy-focused research, which Sassen (2000) has neatly traced through the phases of agricultural and industrial development to a third phase in which women, largely through their migratory initiatives, are protagonists of 'counter-geographies of globalisation', enabling the survival of households in the global South. Also worth noting is the journal Gender and Development, which has addressed an academic and policy readership since 1993.

Summing up, our key point is that while gender perspectives have made major impacts on the literature and thinking about migration and about development, a gendered analysis of remittances, the main linking mechanism between migration and development, is lacking. This is brought out in Figure 1 by the dotted diagonal between gender and remittances, in contrast to the solid lines connecting all other thematic nodes. Thus, gendering remittances is the 'missing link' in our conceptual map of migration, development and gender.

\section{A Gender Agenda for the Study of Remittances}

Where cross-references to gender and remittances are made in the literature, they usually refer simply to the sex of the remitters rather than the underlying gender dynamics that shape individual and household decisions about remittances. Moreover, the evidence is extraordinarily contradictory and does little to illuminate the common assertion that women are better remitters than men because of their caring and altruistic nature (Nyberg Sørensen 2005; Ramírez et al. 2005). It would be tedious to multiply instances of this conflicting evidence, but it seems that for every study that concludes that women are 'better' remitters than 
men, another gives the opposite result, even in the same country. We illustrate this by brief reference to two 'classic' remittance countries, Mexico and the Philippines.

Many Mexican studies, ranging in time from Taylor (1987) to Cohen (2010), indicate that males remit more. Cohen's recent survey data found that males from Oaxaca living abroad remitted on average more than twice as much as women (\$280 against \$130 per month). One interpretation of this pattern is that men are more return-oriented, and so live frugal lives in order to maximize remittances and hasten return, whereas women, who want to prolong their stay in the US, tend to remit less and spend more in situ. Meanwhile, more qualitative research by de la Cruz (1995) argued that Mexican women are more frequent and reliable remitters than men because their remittances are directed to ensuring the livelihoods of their family and siblings, whereas men remit to invest.

Turning to the Philippines, we note similar contradictions in the research evidence. Studying Filipinos in Rome, Tacoli (1999) found that single women, who mostly worked as domestic cleaners and as carers for elderly Italians, sent twice as much in remittances as their male peers in the city. Yet Semyonov and Gorodzeisky (2005), who surveyed 1128 households in the Philippines which had members remitting from abroad, produced the opposite result, even after controlling for variables such as age, marital status and country of destination.

And so it goes on: a story of contradictory evidence and unclear conclusions. ${ }^{4}$ Three further observations can be made, which at first blush complicate, but ultimately advance our understanding, and help us frame our Albanian study. First, different methods of research seem to yield different results. Qualitative field studies tend to support the view that women have a more close and caring relationship to their family members in the home country and hence are more loyal remitters, whereas quantitative surveys seem to record higher remittances from men. Why might this be? One possible answer is that men are more 'open' about their remittances, which are thus more likely to be enumerated and sent through official channels; women's remittances are arguably more likely to be

\footnotetext{
4 Amongst other studies which compare male and female remittance behaviour, several in Thailand generally support the notion of women as superior remitters (Curran and Saguy 2001; Osaki 1999; Vanwey 2004); likewise for Tongans in New Zealand (Vete 1995), Nicaraguans in the US and Costa Rica (Naufal 2007), and Salvadorans in the US (Abrego 2009). Research which favors males includes Cai (2003) on Chinese migrants, Agarwal and Horowitz (2002) on Guyana, and Markova and Reilly (2006) on Bulgarians in Spain.
} 
Accepted Manuscript (AM) of King, R., Castaldo, A. and Vullnetari, J. (2011) Gendered relations and filial duties along the Greek-Albanian remittance corridor. Economic Geography 87(4): 393419 [DOI: 10.1111/j.1944-8287.2011.01128.x][accepted 20 March 2011; published November 2011].

'unofficial', sent through informal channels, even secretly, or presented in the form of in-kind gifts.

A second observation is that each study is set within its own situational context of time, place and migrant group. Different perspectives may be attained if the remittance transfers are measured at their point of origin - the remitters - as opposed to the remittance receivers in the 'home' country. Combining these first two observations, we note the obvious methodological differences between Tacoli's (1999) largely qualitative study of remittance senders in Rome, and Semyonov and Gorodzeisky's (2005) quantitative study of remittance receivers in Manila, whose migrant family members were mostly in the Middle East and East Asia. Our Albanian study responds to these two methodological problems by being multisited, researching both ends of the 'remittance corridor', and by combining a quantitative survey with in-depth interviews.

Thirdly, the studies cited above treat gender as the neutral dichotomous variable of sex. As many studies of gender and migration have shown, gender is a relational concept; the migration (and remittances) behavior of one sex functions very much in relation to the behavior of the other (Bjerén 1997). In other words, gender organizes migration; migration is engendered (Mahler 1999; Pessar 1999). Hondagneu-Sotelo (1994: 3) puts the case both eloquently and succinctly:

Gender is not simply a variable to be measured, but a set of social relations that organize immigrant patterns. The task, then, is not simply... to ask the same questions of migrant women that are asked of migrant men, but to begin with an examination of how gender relations facilitate or constrain both women's and men's immigration and settlement... Gender is exercised in relational and dynamic ways... the social relations of gender contour women's immigration and settlement experiences.

Although there is no mention of remittances in this quote, it is obvious that the same conclusions apply.

A few studies do achieve a more integrated interpretation of the way that remittances are gendered. Rahman and Fee (2009) reveal how Indonesian 
Accepted Manuscript (AM) of King, R., Castaldo, A. and Vullnetari, J. (2011) Gendered relations and filial duties along the Greek-Albanian remittance corridor. Economic Geography 87(4): 393419 [DOI: 10.1111/j.1944-8287.2011.01128.x][accepted 20 March 2011; published November 2011].

migrants in Malaysia send remittances along gender channels, with different purposes and uses. Female migrants remit a greater share of their earnings than males, and they prefer to remit to their mothers and sisters rather than to the men in their families. At the receiving end, female recipients tend to deploy remittances in human capital (food, clothing, education), whilst men invest in physical capital (land, housing and productive assets). Second, McKay's (2005) paper on 'remittance landscapes' in the Philippines is interesting because of the contrast it draws between male and female visions of the future. Migrant women want to use their remittances to buy land and plant staple crops such as rice, ensuring food security, agricultural sustainability and traditional social mobility. Men want to shift from mixed subsistence farming to commercial crops, or purchase chainsaws for logging; their vision of social mobility is through increased cash incomes.

Finally there are studies which focus on how gender relationships are restructured through the power associated with remittances. Lindley's (2009) research on the Somali diaspora in London showed a reordering of a traditional patriarchal society through the feminization of income-earning and remittance sending. Other scholars have looked at the migrant-sending context, where the long-term absence of male remitters results in remittance-receiving wives gaining decision-making power over the use of remittances and the management of the household economy (Conway and Cohen 1998). The case of Ghanaian women in Toronto (Wong 2006) exemplifies the gendered politics of remittances amongst shifting transnational families: women's matrilineal power is strengthened by female-to-female remittances, although not without contestations from male relatives. Wong's study also demonstrates how gendered transnational relationships between remittance senders and receivers are fluid and under constant negotiation.

\section{Researching Gendered Geographies of Power Along the Greece-}

\section{Albania Remittance Corridor}

Out of the foregoing review emerge the following research questions and epistemologies. At the heart of our analysis lies the recursive relationship between gender and remittances identified on Figure 1. How do prevailing gender relations in Albania and amongst Albanian migrant households shape the sending, receiving 
Accepted Manuscript (AM) of King, R., Castaldo, A. and Vullnetari, J. (2011) Gendered relations and filial duties along the Greek-Albanian remittance corridor. Economic Geography 87(4): 393419 [DOI: 10.1111/j.1944-8287.2011.01128.x][accepted 20 March 2011; published November 2011].

and utilization of remittances? And how do the earning, transmission and decision-making about remittances reconfigure gender relations in transnational migrant households? Behind these two complex questions lie a set of simple 'who' questions. Who earns income abroad? Who sends remittances? Who receives remittances? Who decides to whom they should be sent? Who decides how they are spent? Of course, these are not individually arrived-at decisions but are subject to powerful constraints of gender and patriarchy which are still hegemonic within Albanian society; at the same time, migration and remittances have the potential to shift gendered power relations within migrant households, as we shall see presently. We can therefore think of Greece-Albania remittance corridor as a transnational axis where the gendered geographies of power (Mahler and Pessar 2001) are exercised and remodelled as a result of the migration-remittance cycle which flows out and back along this cross-border social and economic space.

In order to avoid the methodological and conceptual shortcomings of much of the literature reviewed above, our research design incorporated the following features.5 First, it was important to acknowledge different household typologies since these fundamentally shape the transfer of remittances as a gendered and generational process. Three main types exist, largely dependent on the marital status of the (male) migrant and whether, if married, he has his wife and children with him in Greece:

- The migrant is single, and remits to his parents in the village;

- The migrant is married, but has migrated alone, so the remittances go to his wife in the village;

- The migrant unit is the nuclear family, so remittances go to parents in the village.

Second, we carried out multi-sited fieldwork in order to cross-check perspectives from both ends of the remittances corridor: a cluster of villages in south-east Albania, and the Greek city of Thessaloniki. Third, we conceptualize remittances as a transnational gendered social practice embedded in transnational kinship relations which include not only financial and in-kind transactions but also 'social remittances' in the form of changing norms, values and behaviors, some of which may involve modifications to gender and generational relations (cf. Levitt 1998;

5 Coincidentally, this closely mirrors the approaches recommended by Kunz (2008), but our research design was put in place before her paper was published. 
Accepted Manuscript (AM) of King, R., Castaldo, A. and Vullnetari, J. (2011) Gendered relations and filial duties along the Greek-Albanian remittance corridor. Economic Geography 87(4): 393419 [DOI: 10.1111/j.1944-8287.2011.01128.x][accepted 20 March 2011; published November 2011].

Pessar and Mahler 2003). Fourth, we employ both quantitative and qualitative techniques, the former based on a questionnaire survey, the latter on narrative extracts from in-depth interviews.

Field data was collected in 2008. After examining municipal demographic records, three adjacent villages in south-east Albania were chosen as broadly representative of the high-emigration regions of southern and central Albania. From this area of origin we traced migrants to Thessaloniki, their main foreign destination. Identification of households to be surveyed in the villages was guided by two criteria: they must have at least one member living in Greece, and they must receive remittances from Greece. The remittance administrator was selected as the interlocutor for the questionnaire, which was administered face-to-face following appropriate screening, consent, and briefing. In a follow-up phase, a number of willing volunteers were re-visited for in-depth interviews. Interviews were also conducted in Thessaloniki with a statistically non-representative but carefully chosen sample of remitting migrant households originating from southeastern Albania. Respondents in both countries included both men and women in order to understand how each group - and particularly women - are involved in the remittance process.

The remittance-recipient survey collected information on four main areas:

1. The demographic situation of the household: bio-data on the respondent and the principal remitter such as age, gender, education, marital status, occupation and migration duration (the latter for the remitter only); as well as on household composition.

2. The housing situation: information about ownership of the dwelling, location, access to water, electricity, telephones and the internet.

3. Information about financial remittances sent by the principal remitter such as sums, frequency, remitting channels, their proportion to overall household income, their use, decision-making on their use, actual investment of remittances in local businesses and future plans in that regard; as well as inkind remittances and their type.

4. Data on various other financial aspects of the household, such as local household income excluding remittances and use of financial products such as loans and bank accounts. 
Accepted Manuscript (AM) of King, R., Castaldo, A. and Vullnetari, J. (2011) Gendered relations and filial duties along the Greek-Albanian remittance corridor. Economic Geography 87(4): 393419 [DOI: 10.1111/j.1944-8287.2011.01128.x][accepted 20 March 2011; published November 2011].

Follow-up interviews were designed to elicit complementary qualitative information not available in the questionnaires, especially regarding gender dynamics and the role of women in the remittance process. ${ }^{6}$ Interviews were taped and transcribed. Questionnaire data were coded and checked and then subject to regression analysis, utilizing two models.

\section{The Setting: Albanian Migration and Patriarchy}

Closed to the outside world for nearly half a century, Albania's exit from the communist years was characterized by suddenly high levels of unemployment, a state of near-starvation, political turmoil, as well as a very young population whose most important dream had been long-denied mobility. The collapse of communism in the early 1990 s was accompanied by massive internal and international migration; it seemed as if the entire country was on the move (Carletto et al. 2006). By 2005, according to Government of Albania figures, over 1 million Albanians were living abroad, equivalent to a third of the country's population (GoA 2005). Greece hosted 600,000, Italy 300,000.

Dominated initially by young, single males, migration streams have become more diverse in recent years in terms of gender, age, education level, professional background, rural and urban origin, as well as motivations for migration. By 2001 Albanian migrant women in Greece and Italy accounted for around 40 percent of Albanians there, according to these host countries' censuses. As migrant men regularize their stay in their host countries, women join them through the process of family reunification, creating the conditions for longer-term settlement. 'Independent' migration of women from rural areas has been rare, the main 'route out' being for university study abroad.

The migration of such a large and diverse section of the population has had significant social and economic impacts. Financial remittances are the most tangible economic impact. Constituting between 10 and 20 percent of the country's GDP since 1992, they have helped maintain macro-economic stability against a

\footnotetext{
6 It needs to be acknowledged that interviewing members of transnational households about remittances has both ethical and response-reliability problems. The personal and private nature of income, wealth and remittances undoubtedly affects the detail and accuracy of the information collected. Self-reported remittance sums must be treated with a degree of caution. Amounts may be inflated to 'upgrade' the social status that comes with higher remittances sent by 'dutiful' sons and 'loyal husbands'; or they may be downplayed when there is a worry that the information given might be used for tax or welfare purposes.
} 
Accepted Manuscript (AM) of King, R., Castaldo, A. and Vullnetari, J. (2011) Gendered relations and filial duties along the Greek-Albanian remittance corridor. Economic Geography 87(4): 393419 [DOI: 10.1111/j.1944-8287.2011.01128.x][accepted 20 March 2011; published November 2011].

huge trade deficit (de Zwager et al. 2005). Their volume has been on the rise from around $\$ 275$ million in 1993 to more than $\$ 1.3$ billion in 2007, then falling over the last two years due to the global economic crisis, which has been particularly severely felt in Greece. As Albania lacks any meaningful production and manufacturing base, there is a growing concern about dependency on remittances (de Zwager et al. 2005; Nikas and King 2005). At a micro-level remittances have been crucial for the survival of entire families and for covering their basic needs for food, decent housing, health and education, as several studies have shown (inter alia Arrehag et al. 2005; De Soto et al. 2002; de Zwager et al. 2005; Frashëri 2007; Gedeshi 2000). Additionally, many businesses rely entirely or partially on this financial capital, especially in the initial set-up phase. Most of these enterprises are small, family-run affairs, often in the retail and hospitality sector, as well as in transport- and construction-related activities (see Castaldo and Reilly 2007; Nicholson 2004; de Zwager et al. 2005).

Despite the transformative effect of migration and remittances on the Albanian economy and on people's regimes of mobility, these changes took place against a much more enduring cultural background of patriarchy and entrenched gender roles. Historians and anthropologists classify Albania as fitting the model of 'Balkan patriarchy' (Kaser 1996: 383), indeed representing its extreme form in some of its regions. Its key features are patrilineality (membership in the family, and thus inheritance, follows the male line), patrilocality (wives move into the house of her husband's father) and strong blood ties (Backer 1983). Both gender and age play a critical defining role in shaping social positions within the family and society, resulting in a supremacy of males and subordination of women within the context of a 'protective' family (Halpern et al. 1996). In terms of age, the eldest males have authority over younger ones, and likewise with females, so that the youngest daughter-in-law has the least power. Although these large families are increasingly making way for smaller, nuclear ones, family retains its centrality in the life of Albanians whether at home or abroad.

Adherence to a set of customary laws called the Kanun is the standard explanatory factor for patriarchy in Albania (Shryock 1988; Whitaker 1981), but this obscures the fact that the 'code' took regionally varied forms, being strongest in the isolated mountains of northern Albania (de Waal 2005: 254). Elsewhere, 
Accepted Manuscript (AM) of King, R., Castaldo, A. and Vullnetari, J. (2011) Gendered relations and filial duties along the Greek-Albanian remittance corridor. Economic Geography 87(4): 393419 [DOI: 10.1111/j.1944-8287.2011.01128.x][accepted 20 March 2011; published November 2011].

notably in the coastal plains and in the far south, the rigid rules of Kanun were diluted by outside influences including - especially in southern Albania - longdistance migration to the United States in the pre-communist era (Vullnetari 2007).

Considerable progress in gender equality was achieved during the communist era. Women were incorporated into the labor force (they had little choice), female literacy improved dramatically, and women made up 30 percent of the People's Assembly between 1970 and 1990 (Brunnbauer 2000; Lamani 2003). In spite of this, the roots of patriarchy in private life were not fundamentally shaken: women continued to carry the major if not sole responsibility for looking after children, the elderly and house chores, in addition to their paid employment; gendered redistribution of these tasks within the home rarely took place.

The post-1990 transition from a command to a market economy and the accompanying restructuring of the labor market have negatively hit women more than men, resulting in a deterioration of access to jobs, pay and working conditions (Moreno-Fontes Chammartin and Cantú-Bazaldúa 2003). At the end of the second post-communist decade men own 92 percent of all property and receive approximately 84 percent of GDP (UNDP-Albania 2008: 13). Political participation and representation have also suffered, particularly as politics continue to display masculinist and at times violent features (Amnesty International 2006). Amidst a power vacuum created by the dissolution of the previously omnipresent state, there was a re-invention of tradition and of strong patriarchal attitudes (Schwandner-Sievers 2006: 224). This was reflected in aggressive attitudes and actions towards women, including curbing their mobility. In particular, independent emigration for rural women was seen with suspicion, as fears and stories of trafficking into prostitution justified the moral and sexual control of young single women by their families - men and older women. Any acts related to women's sexuality or independence which challenge patriarchal authority brought shame on the family and even justified violence (Nixon 2009). This is the background on gender against which contemporary Albanian migration took place. 
Accepted Manuscript (AM) of King, R., Castaldo, A. and Vullnetari, J. (2011) Gendered relations and filial duties along the Greek-Albanian remittance corridor. Economic Geography 87(4): 393419 [DOI: 10.1111/j.1944-8287.2011.01128.x][accepted 20 March 2011; published November 2011].

\section{Gender and Generation Shape Migration and Remittances}

The male-led nature of Albanian emigration has been well documented (Carletto et al. 2006; Hatziprokopiou 2006; King 2003; Vullnetari 2007). Albanian patriarchal relations are the simple explanation for this: fathers and husbands would not allow their daughters and wives to cross the border for fear of losing control over their mobility and sexuality. But this is not the whole story. Part of the explanation also lies in the structure of the migration control regime put in place by the European Union and its constituent states in the wake of the Iron Curtain's disappearance. Apart from a few thousand Albanians admitted as refugees to Italy and other European countries (but not Greece) in 1990-91, there have been very few legal possibilities for Albanian migrants to move to another European country. This has reinforced the 'masculine' risk of clandestine and 'illegal' border crossings trekking over rough mountain paths - which has taken place to Greece on a massive scale, especially during the 1990s.7 However, after a series of regularization schemes started in 1998, many Albanian (male) migrants have been able to stabilize their presence in Greece and bring over their wives and children. ${ }^{8}$

\section{Questionnaire Survey: Key Variables and Summary Results}

The structuring of Albanian emigration - and thereby of transnational households as sender-receiver remittance dyads - by gender and generation was clearly evident in the survey data. Remember, the survey was targeted at the remittance administrator in the village, who reported on the main remitter in Greece. The remittance administrators were divided into two broad groups reflecting different migration patterns: either wives of remitters; or another family member, usually the father (or the mother if the father is ill or deceased) of the remitter. The second of these two remittance dyads (son to father) is the product of two subtypes: either the migrant is single, or, if married, he has his wife and family with him in Greece.

Note that we have gendered the remitter as male. This is - for the time being deliberate. Only 1.1 percent ( 4 out of 350) of the designated remitters in the survey were women. This implies that they are virtually excluded from the sending of

\footnotetext{
7 Some women did undertake such journeys, always, however, in the company of close male relatives; their experiences have been overlooked in the literature.

8 Often this is achieved only with great difficulty, since stay permits need to be continuously renewed, an expensive and time-consuming process, with a high degree of discretionality exercised by Greek officials (Psimmenos and Kassimati 2003).
} 
Accepted Manuscript (AM) of King, R., Castaldo, A. and Vullnetari, J. (2011) Gendered relations and filial duties along the Greek-Albanian remittance corridor. Economic Geography 87(4): 393419 [DOI: 10.1111/j.1944-8287.2011.01128.x][accepted 20 March 2011; published November 2011].

remittances, even though it is known from other research that most of them are income-earners in Greece (Hatziprokopiou 2006; Lazaridis and Koumandraki 2007; Lazaridis 2003). However, regarding the sending of remittances, our interview data reveal a more complex picture, as we shall see later.

For now, we turn to Table 1 which lists the main variables collected by the questionnaire survey and their summary statistics. Results are presented for the sample as a whole and for two sub-groups - wife and 'not wife' as the recipient. Remittances are slightly higher when the receiver is the wife, reflecting the more onerous responsibility the remitter has to his nuclear family than when he is supporting other relatives, such as his parents, who may have other sources of income (farming, pensions) and other remitting sons. Possible remittances from daughters are dealt with later.

It was not thought realistic to ask the remittance recipient for the remitter's income; the remitter's occupation gives, however, an indication of this. According to this variable, 60 percent of remitters work in construction, 28 percent in agriculture and 12 percent in other sectors - including mechanics, plumbers, cooks, bakers and self-employed carpenters. This is quite consistent with previous studies of Albanian immigrants in Greece, especially Thessaloniki (for instance Hatziprokopiou 2006; Pratsinakis 2005) and reflects two contextual aspects: first, the rural background of our survey sample, and second the gendered labor market for migrants in Greece, whereby men work in the sectors mentioned above and women work mainly in care services and retail (Kanellopoulos et al. 2009).

The analysis at subgroup level shows that half of those remitting to their wives work in agriculture; when the remittance administrator is another family member such as a parent, the remitter works mainly in construction, and their participation in the other non-agricultural sectors mentioned above is also much higher than for the first group. Our qualitative fieldwork in Thessaloniki and in the villages shows that this contrast reflects two things: first, the presence of seasonal (male) migrants, who work overwhelmingly in agriculture. They are in Greece for a period of up to six months, while their wife remains in the village combining caring for the children with working in the family plot, as a day laborer in local farms, or in petty trading. Second, the results indicate that remitters who have managed to secure better-paid jobs and live in urban areas have also been able to make family 
Accepted Manuscript (AM) of King, R., Castaldo, A. and Vullnetari, J. (2011) Gendered relations and filial duties along the Greek-Albanian remittance corridor. Economic Geography 87(4): 393419 [DOI: 10.1111/j.1944-8287.2011.01128.x][accepted 20 March 2011; published November 2011].

reunification with their wife and children; therefore they are less represented amongst the first subgroup. Although their incomes are higher, their primary financial responsibility is to their nuclear family in Greece; consequently remittance sums sent to their parents are smaller. The following three quotes from the interviews elaborate on this. First, Ana (age 44), living in the village, describes her seasonal-migrant husband's working regime and the amounts sent back:

He used to go to Greece without documents, then for the last two years he has been going through work visas [valid for six months]. Last year he stayed six months, the year before only five... Last year he brought home $€ 2,800$ [\$3,900]... he wasn't earning a lot, only €25 [\$35] a day... He worked in agriculture; the Greek employer would give him food, but he had other expenses: his cigarettes, buying a telephone card to call us, or perhaps even a beer when he goes out with his friends... He brought less money the first year, because he stayed only five months and he earned less, about $€ 20$ [\$28] per day... he brought home about $€ 2,200[\$ 3,070]$ then.

The second example is from Petrika (46), the father of an unmarried migrant construction worker:

He brings the money himself or sends it through our relatives... The remittances are not always a fixed amount because his work is not always guaranteed and regular. Some months he sends less, other months more... But in a month it's about $€ 200$ [\$280], what is left over after taking care of his expenses there - rent, documents, food etc. If he comes after two or three months, he might bring $€ 500$ [\$670], that's all.

Finally in this trio of quotes we hear from Alide (61), a widow who lives with her unmarried daughter in the village, and dependent on her son, who lives with his own nuclear family in Greece: 
Accepted Manuscript (AM) of King, R., Castaldo, A. and Vullnetari, J. (2011) Gendered relations and filial duties along the Greek-Albanian remittance corridor. Economic Geography 87(4): 393419 [DOI: 10.1111/j.1944-8287.2011.01128.x][accepted 20 March 2011; published November 2011].

He sends about $€ 200$ [\$280] or $€_{300}$ [\$420], sometimes $€ 100$ [\$140], according to what we need... as sometimes we are left without money here. So I tell him: please send us some. Ok, he says, but I need to pay my rent, my documents here first, whatever expenses... then I will send you, don't worry, he tells me. He sends the money sometimes once a month, sometimes once in two or three months.

Returning to Table 1, we see that the mean age of remitters is 34 years, but those remitting to their wives are older (three-quarters are older than 36) than those remitting to other family members (three-quarters below 36 ). The latter category includes many single remitters, understandably younger than marrieds. If we accept that the former group includes seasonal migrants, the findings are quite consistent with recent analyses of Albanian Living Standards Measurement Survey (ALSMS) 2005 data (Azzarri and Carletto 2009).

Although this area, close to the border, has experienced emigration to Greece from the earliest post-communist years, not all migrants have managed, or wanted, to settle long-term in Greece. Even though three-quarters of the remitters are married, only half of them live with their nuclear families in Greece. The rest are either seasonal or have longer-term staying permits and visit home mostly during the winter months and on other occasions. Of those administrator wives who receive remittances from their husbands, the majority live in separate households from their in-laws, indicating nuclear families.

Table 1 also shows, however, that 29 percent of wife-administrators live with their in-laws. This finding is interesting because it represents both conformity to, and potential departure from, customary gender roles. The traditional pattern, as noted earlier, is that men have overall financial responsibility for their families, and any extended family members living in the same household, whilst women perform reproductive and care duties. The patrilinear and patrifocal principles underlying this mean that a daughter's care responsibilities transfer to the family of her husband upon marriage; so she has the duty, especially if her husband is the youngest son, to care for her in-laws and to move there if necessary. She is therefore 'detached' from her own parents, who are cared for by their sons and the 
Accepted Manuscript (AM) of King, R., Castaldo, A. and Vullnetari, J. (2011) Gendered relations and filial duties along the Greek-Albanian remittance corridor. Economic Geography 87(4): 393419 [DOI: 10.1111/j.1944-8287.2011.01128.x][accepted 20 March 2011; published November 2011].

respective wives. This transfer of the married woman to the family lineage of the husband applies also to any income she may earn, including remittances.

Following customary rules, such remittances should be sent to her husband's parents not her own. 9 Within this extended-family system, the decision-maker of the household is the eldest male, i.e. the wife's father-in-law.

However, in these 29 percent of households where the wife lives with her inlaws and yet is the remittance-administrator, some adjustment of traditional norms has evidently taken place. Our field observations and interview data revealed two main circumstances at play. In some cases there had been a switch in intra-household power relations in favor of the migrant's wife. In other cases the reasons were more pragmatic: the in-laws were very elderly or unwell, sometimes bed-ridden. We came across several cases where the migrant's wife had stayed in the village purely because she had to look after the ailing parents of her husband. Thus, what appears to be a relaxation of traditional gender roles (the wife becoming the remittance administrator) is actually a result of conformity to ageold gendered duties of care. Elvira (30), interviewed in Thessaloniki, explained how she had been constrained to stay with her parents-in-law to look after them; only later (after the youngest son had married, and his wife took over the caring duties) could she join her husband in Greece:

My husband was the eldest son... His younger brother was not married then and my mother-in-law was paralyzed, bed-ridden. I could not leave her and go as there was no one else to care for her... When he got married I then joined my husband in Greece.

Moving to the household income net of remittances, our results show that for a third of households this is below 100,000 lek $[\$ 1,000]$ per year. A similar share of households belong to the next income group of 100,000-200,000 lek per year. When we consider that, for more than half of the surveyed households, remittances constituted more than half of their household income, the importance of such capital transfers becomes clear. This is especially the case in (often nuclear)

\footnotetext{
9 This pattern was found to operate amongst Albanian migrants in London, who mainly came from the remote highlands of northern Albania where traditional practices traceable to the Kanun are more entrenched (King et al. 2006).
} 
Accepted Manuscript (AM) of King, R., Castaldo, A. and Vullnetari, J. (2011) Gendered relations and filial duties along the Greek-Albanian remittance corridor. Economic Geography 87(4): 393419 [DOI: 10.1111/j.1944-8287.2011.01128.x][accepted 20 March 2011; published November 2011].

families where the male remitter sends money to his wife and children. Nearly 60 percent of such households are in the lowest income group, which means that these women have either very limited access to local income-generating sources, or they are restricted in the degree to which they can take up various activities, as they have to look after their children. Donika's family is one such case. Aged 37, she lives in the village with her four children of between seven and 19, while her husband works in Greece. Remittances are the only real income in the family. But she is far from the passive remittance receiver some literature might suggest, as this quote from her interview reveals:

... During the summer he sends around $€ 500-€ 600$ [ $\$ 670-\$ 840]$ up to $€ 1,000$ [\$1,400] every month or every two months... But around October or November we start feeling the strain because there is less work then, and we start tightening our belts... I am hoping every day that we can join him in Greece because there is no future here. I want to work, to work hard, I will do any job so that I can earn money in an honest way. If I can't work to support my family, my children, now that I am young, when will I? But the problem is the papers [entry and stay permits for Greece].

We also looked at household size, net of the emigrant remitter. When remittances are sent to households where the wife is the administrator, the vast majority of these families are of average size (3-4 persons). In households where another family member (i.e. not the wife) is the administrator, however, the majority goes towards small households. These are often single or couple elderly parents who live in the villages on their own after all their children and grandchildren have emigrated abroad.

Besides the primary remitter, money is sent by one or more additional migrants in 18 percent of cases (Table 1). Most often these are older sons who remit small sums to their parents 'just for coffee', to make them happy by showing respect and love rather than out of the main filial duty of care and maintenance which belongs to the youngest son. Only in few cases were these daughters who sent 'coffee 
Accepted Manuscript (AM) of King, R., Castaldo, A. and Vullnetari, J. (2011) Gendered relations and filial duties along the Greek-Albanian remittance corridor. Economic Geography 87(4): 393419 [DOI: 10.1111/j.1944-8287.2011.01128.x][accepted 20 March 2011; published November 2011].

money', the almost universal euphemism for 'unofficial' remittances. Here follow illustrative quotes from two migrants in Greece - first Fatmir (42), then Irena (37):

When I was alone here, I had an obligation to send some money and I would try to send as much as possible... It was approximately... $€ 200-€ 300$ [ $\$ 280-\$ 420]$ a month, I had an obligation to send because... they needed money to survive... Whereas now I send them something small... $€_{50}[\$ 70] \ldots$ for a coffee... If they were with me [meaning if he had the responsibility of looking after them - he is the eldest of the four brothers], it would be different.

We don't send much money to Albania now. Because Kosta's [her husband] parents are not there anymore [they have died]. Whereas my parents are with my brother, he looks after them according to tradition in Albania. We send them a little package, or a little something [money], as a dhoro [Greek for present]... around €20 [\$28] a month just for a coffee.

Finally, on remittance uses we see that more than half of recipient households spend them on repairing, refurnishing and constructing a house, a third uses them to pay for the pension (social insurance) premiums, some households put them in savings, while a tenth pay off migration debts. We note that wife-administrator households use more for housing than the other household types, as well as more to pay off debt. Elona, 40, who lives in the village with her two children, explains:

I try to use the money wisely: for the house, for food, to buy clothes for the children, to pay for their school items because they need things like notebooks, pens etc.

\section{Regression Analysis}

Tables 2 and 3 relate to two separate models. In Table 2 the model does not include variables on the use of remittances, whereas they are part of the analysis in the second model, Table 3. Both tables have three columns which refer respectively 
Accepted Manuscript (AM) of King, R., Castaldo, A. and Vullnetari, J. (2011) Gendered relations and filial duties along the Greek-Albanian remittance corridor. Economic Geography 87(4): 393419 [DOI: 10.1111/j.1944-8287.2011.01128.x][accepted 20 March 2011; published November 2011].

to the sample as a whole, and the same two subgroups described earlier. We start with Table 2 and the remitter's occupation. Migrants working in agriculture send significantly lower remittances than those employed in other occupations. However, occupation as a factor which impacts on remittance behavior is only significant for those households where the wife is the remittance administrator.

The age of remitter shows a U-shaped relationship with the amount of remittances sent, i.e. the youngest and oldest migrants remit more than middleaged ones. In contrast to occupation, however, this factor is only significant for households where someone other than the wife administers remittances. Here, single men who are also in the youngest age group, remit to support their parental household, as well as to save for the start of their own family - as we shall see shortly. Older migrants, on the other hand, remit more because they have been working longer in Greece. The middle-age ones are mostly those who have settled with their wives and children in Greece and send sporadically to parents. In the Albanian tradition, it is accepted that, once married, sons take care of their nuclear families as a priority and then help parents according to ability.

There is a positive relationship between education and sums remitted; the correlation is highly significant only when remittances are sent to parents. This indicates the likely importance of remittances sent to repay family investment in education, supporting Lucas and Stark's (1985) argument that the positive effect of education on remittances is greater when the remitter is the child of the household head as opposed to when the sender is the spouse or other household member.

Duration of migration, too, increases the amounts remitted. Migrants who have been working in Greece for five years or more will remit significantly more than those of shorter duration. This effect is quite understandable when we consider that emigration experience is positively related to learning the language, creating networks and enhancing skills, thereby increasing the chances of accessing betterpaid and more stable jobs. To some extent, this finding runs counter to prevailing thought on remittances, namely that, with increasing duration of migration, remittances will lessen as the migrant will become more integrated into the host society. The contradiction is partly explained by different time-frames. Our study dichotomized length of stay into fewer and more than five years, a cut-off which often corresponds to the passage from an irregular to a legal status. Lucas and 
Accepted Manuscript (AM) of King, R., Castaldo, A. and Vullnetari, J. (2011) Gendered relations and filial duties along the Greek-Albanian remittance corridor. Economic Geography 87(4): 393419 [DOI: 10.1111/j.1944-8287.2011.01128.x][accepted 20 March 2011; published November 2011].

Stark (1985) find that diminution of remittances does not occur within the first five years, only later. For Albania De Zwager et al. do forecast declining remittances after a longer time-frame, although their evidence to back this up is somewhat speculative (2005: vi-viii).

In terms of marital status and family situation, being single increases the value of remittances significantly. Young single men remit to fulfill their filial duty towards their parents and younger siblings, but also in order to accumulate capital to start their own families. Besmir (24, Thessaloniki) says:

I always take money with me when I visit... usually every two or three months I go and visit... I put some in my bank account and give the rest to them [his parents]... The amount depends on the work I do... Sometimes I work for a big firm as a plumber, sometimes I take a project myself...So it's about $€ 2,000[\$ 2,790]$ in two or three months that I take with me to Albania.

Furthermore, having children in Albania is a highly significant incentive to remit more, as is the case when the remittance administrator is the remitter's wife. This finding is quite consistent with other literature on Albanian migration which finds that most remittances are sent to spouses with children and to parents (Balliu 2007; King and Mai 2008: 228-34).

Continuing with the household income, the relationship progresses positively upwards with the most affluent families (those earning more than 200,000 lek or $\$ 2,000$ a year excluding remittances) also attracting the highest remittance sums. However, this relationship becomes insignificant for the subgroup of households where the wife administers remittances. Based on interview and observational data, the reasons for this are as follows. First, more affluent families will send migrants who have higher levels of education, who in turn get better and more stable jobs in Greece and can send more remittances. Second, even if a household was poor in the beginning, remittances may have boosted living standards as well as developing other activities such as livestock and apple orchards, which in turn bring in better income than subsistence agriculture. In addition, the first subgroup may not want to invest in Albania as their intention may be for the wife and 
Accepted Manuscript (AM) of King, R., Castaldo, A. and Vullnetari, J. (2011) Gendered relations and filial duties along the Greek-Albanian remittance corridor. Economic Geography 87(4): 393419 [DOI: 10.1111/j.1944-8287.2011.01128.x][accepted 20 March 2011; published November 2011].

children to join the migrant man in Greece, once he has been able to arrange longterm staying permits and a stable job there. Thus, the finding in this context is again consistent with the position that migrants remit not only because of altruism but are also motivated by exchange or investment factors (Lucas and Stark 1985).

Finally, with regard to household size, it seems the more numerous the household, the more remittances are received. However, this is significant only in the case of wife administrators (i.e. in households with more children and/or very old parents).

The results from Model 2 (Table 3), with remittance uses as additional variables, are generally similar to those of Model 1 although, as expected, the importance of most variables as determinants of remittance sums has weakened somewhat. On the other hand, uses of remittances appear to influence to a highly significant degree the sums remitted, as shown by the individual statistical significance of their estimated coefficients in the relevant rows of Table 3, and also by their joint statistical significance (reported in the bottom row)..$^{10}$ This is generally the case when they are used as savings, to pay for pension premiums, and housing; however, where wives administer remittances, the amount received is not influenced by their use to cover pension premiums, reflecting the younger ages of family members such as children. An interesting result is that those who spend part of their remittances to pay off migration debt (smuggler's fees, visa cost etc.) are also those who receive the least remittances. When we tie this with results which relate to household income and remittance as presented in all three tables, our findings suggest that the poorest households also benefit the least from migration and remittances. First, they receive less remittances; second they use them disproportionately more to pay off debts incurred in order to emigrate. Wifeheaded households are the group most negatively impacted in this way.

\footnotetext{
${ }^{10}$ The overall $\mathrm{R}^{2}$ values of Tables 2 and 3 are within the range expected for remittance analyses of this type. We ran a check on several other studies and whatever the context, sample size and estimation method adopted, $\mathrm{R}^{2}$ values ranged between 0.20 and 0.50 . The F-test at the foot of Table 3 shows that the increase in $\mathrm{R}^{2}$ from Model 1 to Model 2 is indeed statistically significant, i.e. it is most likely not to be due to chance but to a real effect of the variables on use of remittances. However, we acknowledge that the results of Model 2 should be interpreted with caution, since the additional variables included are not standard in empirical studies of remittance behavior (cf. de la Brière et al. 2002; Gubert 2002; Liu and Reilly 2004; Lucas and Stark 1985), unlike the variables we used in Model 1.
} 
Accepted Manuscript (AM) of King, R., Castaldo, A. and Vullnetari, J. (2011) Gendered relations and filial duties along the Greek-Albanian remittance corridor. Economic Geography 87(4): 393419 [DOI: 10.1111/j.1944-8287.2011.01128.x][accepted 20 March 2011; published November 2011].

\section{Remittances, Women and Patriarchy}

Having demonstrated that gender and generation are fundamental shapers of the remittance process in Albania, we now reverse the analysis and look at how remittances have the effect of reshaping gender and patriarchal relations. The short answer to this question is 'to some extent but on the whole not very much'. However, some changes are taking place which were uncovered in the interviews and from other fieldwork (King and Vullnetari 2009a). Basically, these relate to the 'who' questions listed earlier. Who sends remittances to whom? Who decides on how remittances are to be spent? And are there signs that administering remittances empowers women in Albania?

\section{Steps Towards the Feminization of Remittances}

Although women as 'primary remitters' hardly existed amongst our questionnaire survey, we discovered from the in-depth interviews that women were not excluded from remitting, although they were generally involved to a much lesser extent than their husbands. Money sent by married daughters to their parents or to other relatives on their side of the family flouted the patrilinear principle of channelling all remittances to the husband's family, but nevertheless was 'allowed' in some migrant households. Such 'deviant' remittances were not called remittances but were generally referred to as 'presents' or 'just for a coffee', as noted earlier. From the side of the parents, receiving remittances from (married) daughters was considered out of the ordinary and sometimes even shameful, since it implied failure of the sons in their filial duty to support their parents. ${ }^{11}$ Partly for these reasons, we found hints and references to semi-secret remittances which mainly involved daughter-to-mother and also sister-to-sister transfers, usually in the form of gifts or small amounts of cash (see also Smith 2009, who has interesting ethnographic data on this from another part of southern Albania).

Another arrangement which indicates a softening of 'traditional' male-lineage arrangements is when remittances are pooled and sent to both sets of parents. Fatmir (42) has been in Greece for nearly twenty years, initially alone, now with his wife and children:

\footnotetext{
${ }^{11}$ For this reason daughters-only families were regarded as 'unfortunate' since there were no sons to send remittances or support the parents in their old age, or indeed to continue the family's blood line.
} 
We also send money to my in-laws... otherwise it would be unfair; she [wife] also works and is far away from her parents...

Berti (47), who had been living in Thessaloniki with his wife and two sons for more than ten years, expressed similar thoughts:

Like I send money to my mother, my wife also sends money to her mother... there is no difference, because she works and I work...We send the money as a kind of pension... every two or three months, we send them about $€ 1000[\$ 1,400]$ each, so that they have enough to live on... When they need something special, we might send them more.

The difference here is that Berti's wife comes from a family with two daughters and no sons. The youngest daughter is unmarried and looks after her widowed mother. So the financial care responsibility in this case has shifted to the only son-in-law.

In the following quote, Alket (42, Thessaloniki) draws a contrast between what he calls 'decent' families, like his own, and those headed by 'men with moustaches' - meaning patriarchal men, described in this way because in the communist-era movies old patriarchs wore bushy moustaches.

As for my wife's family, when we go there to visit, my wife gives a present to my in-laws. Of course, it goes without saying: how can you not when you are together husband and wife in the family? How can we take something to my father and not to her father? I'm talking about decent $[e$ rregullt $]$ families. If you are a man with a moustache, an Albanian man like that, then I don't know. But today women play a big role in the family...

\section{Receiving Remittances and Deciding How They Are Used}

The survey data showed that in recipient households where the son was the primary remitter, the father was most likely to be the administrator of these 
remittances; however, mothers were not far behind (28 as against 41 percent of all survey respondents). On the face of it this indicates something approaching gender equality, but in many cases the mothers were widows, reflecting the traditionally rather large age difference between marriage partners in Albania. In actual fact, considerable ambiguity surrounds the issue of receiving and spending money on the part of parents of migrants. Often the male pre-eminence in these matters was acknowledged as more symbolic than real, since it is really the women who "hold the purse' in the household, because 'of course women know what is needed in the house' (Anila, 25, Thessaloniki). ${ }^{12}$ Some of these nuances are brought out in the following two quotes, the first from Gimi (30), the second from Sokol (50), both interviewed in Thessaloniki:

I give the money to my father - because it makes him happy, you understand. The money will end up in the hands of my mother anyway. But, father feels happy if I do this, like I show respect... Mother administers the money, she has the purse... But the orders are given by father, of course... But I don't doubt that they both discuss how it will be used.

I give it to my father... My mother keeps the money that is needed for the household, she keeps the purse. But father goes out with his friends every day to have a coffee, to go for a stroll, so he needs to have some money in his pocket, as a man... At the end of the day, all the money comes into the hands of my mother, but it is a little difficult for father to go and ask her each time: give me 100 or 500 lek because I'm going out. So I give him some pocket money to have it with him whenever he needs it.

In the female-headed households where the remittance administrator was the wife of the migrant husband (just under 30 percent of the survey total), the question is not who receives the money but who takes the decisions over how it is

\footnotetext{
${ }^{12}$ The reference to 'holding the purse' is a common phrase which harks back to when money - or the key to where it was locked - was kept in a little cloth pouch kept by the holder in an inside pocket at all times.
} 
Accepted Manuscript (AM) of King, R., Castaldo, A. and Vullnetari, J. (2011) Gendered relations and filial duties along the Greek-Albanian remittance corridor. Economic Geography 87(4): 393419 [DOI: 10.1111/j.1944-8287.2011.01128.x][accepted 20 March 2011; published November 2011].

spent. In these cases where the husband is away long-term and returns only for short visits, the wife assumes most of the decision-making power; in those where the husband is a seasonal migrant, he takes over the financial management when he is back in Albania. Tensions sometimes arise over this fluctuating responsibility, and over what priorities should be given to remittance usages when competing claims come from different members of the household: this is especially the case when the household is large and composed of different generations. A common tension is that between the males of the household, who want to invest in 'metal' (as one female interviewee put it, meaning farm machinery or a vehicle), and women whose priority is the 'house' (kitchen equipment, furnishings etc.). Age may also be a relevant influence, complicating the dynamics of household discussions over remittances further. This cross-cutting tension between gender, age and generations is well illustrated in the following interview clip from a threegeneration recipient household: the teenage daughter is the vocal one, illustrating the increasing self-confidence of Albania's younger generation, but ultimately it is the oldest male (the migrant's father) who decides, with some input from the son:

Migrant's wife: In my family it is my father-in-law or myself who receives these remittances... Then it is my husband and my father-inlaw who decide what they will be spent on...

Teenage daughter: There are three generations in our family and we all have different ideas. I want books for school for instance, or I need this item of clothing which I must absolutely have. Whereas my mother says we need this or that for the house, and granddad says we need this or that for the apple orchard. And so a certain disagreement arises... but of course this doesn't escalate...

Wife: So everyone has different priorities...

Grandmother: Everyone has their own ideas...

Teenage daughter: We all try to meet our own needs, although it is the eldest in the family... who knows where this or that money will go, so that all are satisfied in the end.

Wife: So in the end, it is the head of household who gives the final verdict. 
Accepted Manuscript (AM) of King, R., Castaldo, A. and Vullnetari, J. (2011) Gendered relations and filial duties along the Greek-Albanian remittance corridor. Economic Geography 87(4): 393419 [DOI: 10.1111/j.1944-8287.2011.01128.x][accepted 20 March 2011; published November 2011].

\section{Remittances and Gender Roles: Increased Burden or Empowerment?}

Our interview evidence shows mixed outcomes in response to this question.

Women who de facto were heads of their households whilst their husbands worked in Greece did not always enjoy enhanced power over decision-making in the family. Even when abroad, most husbands retained an important role in deciding family affairs and the spending of remittances; this was especially the case for bigger things than just everyday expenses, such as investing in property or farming.

Women, for their part, enjoyed an improved standard of living and some aspects of their work had been made easier due to the use of remittances to purchase household goods such as washing machines, heating and cooking appliances, better furniture etc. In some cases, women had the freedom to withdraw from the labor market both to avoid tough work in the fields and to enjoy the enhanced social status that this indication of prosperity brought. This outcome was counterbalanced by other cases where women felt overburdened by the multitude of tasks and responsibilities they had to take on in the absence of their husbands bringing up children, following their education, taking care of the house and perhaps (if remittances were not substantial) working the land and looking after livestock too. Flutur (47, village interview) gave her version of this ambiguous situation with regard to decision-making, extra responsibility and burden-bearing:

Yes, he is the one who directs [i.e. who is nominally in charge of the family]... but when my husband is over there [in Greece], I am the one sorting out things... When our daughter comes home and asks for money, I am the one giving her how much she needs, I manage the economy... My responsibilities have increased, I have to take care of everything myself: the land, the house, the children, all the weight is upon me. He is [involved], but over the phone... I am the one everyone comes to, for good or bad.

Finally, for both migrants in Thessaloniki and their family members in the villages in Albania, the emotional costs of family separation were a major issue. Husbands were separated from wives, fathers from children, grandparents from their children and grandchildren. While the economic benefits of remittances are 
Accepted Manuscript (AM) of King, R., Castaldo, A. and Vullnetari, J. (2011) Gendered relations and filial duties along the Greek-Albanian remittance corridor. Economic Geography 87(4): 393419 [DOI: 10.1111/j.1944-8287.2011.01128.x][accepted 20 March 2011; published November 2011].

duly praised, the human costs and the sacrifices made need to be acknowledged too.

\section{Conclusion}

This paper has demonstrated the value of an in-depth conceptualization and investigation of the recursive relationship between gender and remittances within the specifics of Albania's patriarchal society and migration flows to neighboring Greece - one of the most dramatic cases of the renewed role of remittances in the new world order (Jones 1998). A multi-sited, mixed-method research design has enabled us to overcome some of the epistemological shortcomings of earlier studies of gendering remittances which have employed sex as a simple dichotomous variable, or focused just on the sending or the receiving context, or dealt with small-N qualitative samples.

How have remittances and gender interacted with each other in shaping development in Albania? To reprise Hondagneu-Sotelo (1994: 3), gender organizes both migration and remittances in Albania - fundamentally so. Both are structured by a combination of gender, patriarchy and generations bound by kinship obligations that change little over time; indeed in some respects they are even reinforced by migration and remittance duties. In other words, and echoing another conceptual framework introduced earlier, the gendered geographies of power expressed along the Albania-Greece migration and remittance corridor remain patriarchially structured.

This generalization, valid at an aggregate level, needs refinement when applied to specific situations. Accordingly we mapped out remittance dyads between different remittance-receiving households (wife and children, wife and multigeneration household, father/parents/widow) and sending units (single man, married man with family in Albania, nuclear family). This disaggregated approach, which corresponds to the reality of how remittances are transferred and administered, enabled us to demonstrate the ways in which migration and remittances did lead to a partial reconfiguring of gender and generational relations. Filial and spousal roles and duties remain paramount, but we were able to uncover, during in-depth interviews, some reallocation of agency towards women both as remitters and receivers. This was particularly the case when the definition of 
Accepted Manuscript (AM) of King, R., Castaldo, A. and Vullnetari, J. (2011) Gendered relations and filial duties along the Greek-Albanian remittance corridor. Economic Geography 87(4): 393419 [DOI: 10.1111/j.1944-8287.2011.01128.x][accepted 20 March 2011; published November 2011].

remittances was broadened to include gifts and other in-kind transfers, as well as a linguistic accommodation of money transfers falling outside the patriarchal norm, expressed in the common phrase 'just for a coffee'.

The broader question of how remittances, as a form of transnational gendered social practice, have impacted Albanian development, is much more difficult to answer, since it involves deeper and more complex questions about migration and the meaning of development. For sure, mass emigration has been many Albanians' response to the accumulated underdevelopment and 'shared poverty' of the communist era and the 'new poverty' of the chaotic transition years. The ensuing remittances have enabled a significant share of Albanian households, especially in rural areas, to lift themselves out of poverty (De Soto et al. 2002; Zezza et al. 2005). The extent to which such remittances have moved beyond the 'economic survival' stage to one of stimulating longer-term development remains an open question, since the barriers to endogenous development (corruption, weak civil society, lack of credit, deficient infrastructures etc.) remain strong (King and Vullnetari 2009b).

There is little evidence that remittances have significantly empowered women into real leadership positions either within their transnational households or in the development process more widely. Thus far, changes have been tokenistic rather than fundamental. Within migrant households in Greece, the necessity of accessing work to maximize earnings gives women a small measure of independence and freedom to move around the city, and some sharing of household chores and childcare may occur, but these changes reflect the pragmatic constraints of life as a migrant household earning low wages rather than the emancipatory features of Greek society - which remains, in fact, quite patriarchal itself. For these women who remain in, or return to, Albania, not much changes, except an increased burden of household management if the family's menfolk remain in emigration.

There is lots of scope for further research on gendering remittances. Following Wong (2006: 376), we need to continue to look beyond traditional views of remittances as economic transactions and regard them as contextualized gendered social practice. As Carling (2008) and Kunz (2008) argue, universal claims about remittances and gender are difficult to make since gender is socially and culturally constructed, while remittances are also affected by specific migratory contexts as 
well as global labor and money markets. Our Albanian case study demonstrates this very well. Survey data can tell the researcher only so much. The careful collection of narrative evidence, especially from women, is necessary in order to probe deeper into these structures and processes and understand how men and women negotiate power and reconfigure gender relations across transnational households and societies. Again as Wong suggests (2006: 376), more women's voices need to be heard if we are to fully understand the key issues at the intersections of migration, remittances, gender, culture and development.

Author adressess:

Prof. Russell King, Department of Geography, School of Global Studies, University of Sussex, Falmer, Brighton, BN1 9SJ, UK.

email R.King@sussex.ac.uk (corresponding author).

Dr Adriana Castaldo, Sussex Centre for Migration Research, School of Global Studies, University of Sussex, Falmer, Brighton, BN1 9SJ, UK. email A.Castaldo@sussex.ac.uk

Dr Julie Vullnetari, Sussex Centre for Migration Research, School of Global Studies, University of Sussex, Falmer, Brighton, BN1 9SJ, UK. emailJ.Vullnetari@sussex.ac.uk

\section{Acknowledgements:}

The research on which this paper is based was financed by UN-INSTRAW (The United Nations International Training and Research Institute for the Advancement of Women) under their project 'Gender and Remittances: Building Gender-Responsive Local Development'. 
Accepted Manuscript (AM) of King, R., Castaldo, A. and Vullnetari, J. (2011) Gendered relations and filial duties along the Greek-Albanian remittance corridor. Economic Geography 87(4): 393419 [DOI: 10.1111/j.1944-8287.2011.01128.x][accepted 20 March 2011; published November 2011].

\section{References}

Abrego, L. 2009. Economic well-being in Salvadoran transnational families: how gender affects remittance practices. Journal of Marriage and the Family 71(6): 1070-85.

Agarwal, R., and Horowitz, A.W. 2002. Are international remittances altruism or insurance? Evidence from Guyana using multiple-migrant households. World Development 30(11): 2033-44.

Amnesty International. 2006. Albania: violence against women in the family, 'it's not her shame'. London: Amnesty International.

Arrehag, L., Sjöberg, Ö., and Sjöblom, M. 2005. Cross-border migration and remittances in a post-communist society: return flows of money and goods in Korçë district, Albania. South Eastern Europe Journal of Economics 3(1): 9-40.

Azzarri, C., and Carletto, C. 2009. Modelling migration dynamics in Albania: a hazard function approach. Southeast European and Black Sea Studies 9(4): 407-33.

Backer, B. 1983. Mother, sister, daughter, wife: the pillars of traditional Albanian patriarchal society, in Women in Islamic societies: social attitudes and historical perspectives, ed. B. Utas, 48-65. London: Curzon.

Balliu, Q. 2007. Enhancing the impact of migrant remittances in Albania by creating an integrated migrant remittances system. Study on remittances for potential local economic development in Vlora region. Tirana: IOM and ILO.

Bjerén, G. 1997. Gender and reproduction, in International migration, immobility and development: multidisciplinary perspectives, eds. T. Hammar, G. Brochmann, K. Tamas and T. Faist, 219-46. Oxford: Berg.

Boyle, P. 2002. Population geography: transnational women on the move. Progress in Human Geography 26(4): 531-43.

Brunnbauer, U. 2000. From equality without democracy to democracy without equality? Women and transition in South-East Europe. South-East Europe Review 3(3): 151-68.

Cai, Q. 2003. Migrant remittances and family ties: a case study in China.

International Journal of Population Geography 9(6): 471-83. 
Accepted Manuscript (AM) of King, R., Castaldo, A. and Vullnetari, J. (2011) Gendered relations and filial duties along the Greek-Albanian remittance corridor. Economic Geography 87(4): 393419 [DOI: 10.1111/j.1944-8287.2011.01128.x][accepted 20 March 2011; published November 2011].

Carletto, G., Davis, B., Stampini, M., and Zezza, A. 2006. A country on the move: international migration in post-communist Albania. International Migration Review 40(4): 767-85.

Carling, J. 2008. Integrating remittances: more questions for deeper insight and better policies, in Migration and development: perspectives from the South, eds. S. Castles and R. Delgado Wise, 43-64. Geneva: IOM.

Castaldo, A., and Reilly, B. 2007. Do migrant remittances affect the consumption patterns of Albanian households? South Eastern Europe Journal of Economics 1(1): 25-54.

Castles, S., and Delgado Wise, R. eds. 2008. Migration and development: perspectives from the South. Geneva: IOM.

Cohen, J. 2010. Oaxacan migration and remittances as they relate to Mexican migration patterns. Journal of Ethnic and Migration Studies 36(1): 149-61.

Conway, D., and Cohen, J. 1998. Consequences of migration and remittances for Mexican transnational communities. Economic Geography 74(1): 26-44.

Curran, S., and Saguy, A.C. 2001. Migration and cultural change: a role for gender and social networks. Journal of International Women's Studies 2(3): 5477.

de Haas, H. 2005. International migration, remittances and development: myths and facts. Third World Quarterly 26(8): 1269-84.

de la Brière, B., Sadoulet, E., de Janvry, A., and Lambert S. 2002. The roles of destination, gender, and household composition in explaining remittances: an analysis for the Dominican Sierra. Journal of Development Economics 68(2): 309-28.

de la Cruz, B. E. 1995. The socio-economic dimensions of remittances: a case study of five Mexican families. Berkeley McNair Journal 3: 1-10.

De Soto, H., Gordon, P., Gedeshi, I., and Sinoimeri, Z. 2002. Poverty in Albania. A qualitative assessment. Washington DC: World Bank technical paper 520.

de Waal, C. 2005. Albania today: a portrait of post-communist turbulence. London: I.B. Tauris.

de Zwager, N., Gedeshi, I., Germenji, E., and Nikas, C. 2005. Competing for remittances. Tirana: IOM Tirana. 
Accepted Manuscript (AM) of King, R., Castaldo, A. and Vullnetari, J. (2011) Gendered relations and filial duties along the Greek-Albanian remittance corridor. Economic Geography 87(4): 393419 [DOI: 10.1111/j.1944-8287.2011.01128.x][accepted 20 March 2011; published November 2011].

Frashëri, A. 2007. Nationwide remittance beneficiaries survey. Bank of Albania Economic Bulletin 10(3): 63-80.

Gedeshi, I. 2000. Roli i remitancave të emigracionit shqiptar e ndikimi i tyre në ekonominë e vendit. Politika dhe Shoqëria 1(2): 55-68.

Glick Schiller, N. and Faist, T. 2009. Migration, development and social transformation. Social Analysis 53(3): 1-13.

GoA. 2005. National Strategy on Migration. Tirana: Government of Albania (GoA) and IOM.

Gubert, F. 2002. Do migrants insure those who stay behind? Evidence from the Kayes Area (Western Mali). Oxford Development Studies 30(3): 267-87.

Halpern, J., Kaser, K., and Wagner, R. 1996. Patriarchy in the Balkans: temporal and cross-cultural approaches. The History of the Family 1(4): 425-42.

Hammar, T., Brochmann, G., Tamas, K., and Faist, T., eds. 1997. International migration, immobility and development. Oxford: Berg.

Hatziprokopiou, P. 2006. Globalisation, migration and socio-economic change in contemporary Greece: processes of social incorporation of Balkan immigrants in Thessaloniki. Amsterdam: Amsterdam University Press.

Hondagneu-Sotelo, P. 1994. Gendered transitions: Mexican experiences of immigration. Berkeley: University of California Press.

Jones, R.C. 1998. The renewed role of remittances in the new world order. Economic Geography 74(1): 1-7.

Kanellopoulos, K., Gregou, M., and Petralias, A. 2009. Size profile and labour market analysis of immigration in Greece. Athens: Centre of Planning and Economic Research, Report 59.

Kapur, D. 2004. Remittances: the new development mantra? Geneva: G-24 discussion paper 29.

Kaser, K. 1996. Introduction: household and family contexts in the Balkans. The History of the Family 1(4): 375-86.

King, R. 2003. Across the sea and over the mountains: documenting Albanian migration. Scottish Geographical Journal 119(3): 283-309.

King, R., Dalipaj, M., and Mai, N. 2006. Gendering migration and remittances: evidence from London and Northern Albania. Population, Space and Place 12(6): 409-34. 
Accepted Manuscript (AM) of King, R., Castaldo, A. and Vullnetari, J. (2011) Gendered relations and filial duties along the Greek-Albanian remittance corridor. Economic Geography 87(4): 393419 [DOI: 10.1111/j.1944-8287.2011.01128.x][accepted 20 March 2011; published November 2011].

King, R., and Mai, N. 2008. Out of Albania: from crisis migration to social inclusion in Italy. Oxford: Berghahn.

King, R., and Vullnetari, J. 2009a. The intersections of gender and generation in Albanian migration, remittances and transnational care. Geografiska Annaler: Series B, Human Geography 91(1): 19-38.

King, R., and Vullnetari, J. 2009b. Remittances, return, diaspora: framing the debate in the context of Albania and Kosova. Southeast European and Black Sea Studies 9(4): 385-406.

Kofman, E. 2004. Gendered global migrations. International Feminist Journal of Politics 6(4): 643-65.

Kunz, R. 2008. 'Remittances are beautiful'? Gender implications of the new global remittances trend. Third World Quarterly 29(7): 1389-409.

Lamani, M. 2003. Gratë në Kuvend. Tirana: Kuvendi i Shqipërisë. Sektori i Kërkimit dhe Biblioteka.

Lazaridis, G. 2003. From maids to entrepreneurs: immigrant women in Greece, in Gender and insecurity, ed. J. Freedman, 173-94. Aldershot: Ashgate.

Lazaridis, G., and Koumandraki, M. 2007. Albanian migration to Greece: patterns and processes of inclusion and exclusion in the labour market. European Societies 9(1): 91-111.

Lerch, M., and Wanner, P. 2005. Les facteurs déterminants de la réception de transferts de fonds des migrants et leur impact sur la pauvreté en Albanie. Geographica Helvetica 60(3): 201-9.

Levitt, P. 1998. Social remittances: migration driven local-level forms of cultural diffusion. International Migration Review 32(4): 926-48.

Lindley, A. 2009. The early-morning phonecall: remittances from a refugee diaspora perspective. Journal of Ethnic and Migration Studies 35(8): 131534 .

Liu, Q., and Reilly, B. 2004. Income transfers of Chinese rural migrants: some empirical evidence from Jinan. Applied Economics 36(12):1295-1313.

Lucas, R. E., and Stark, O. 1985. Motivations to remit: evidence from Botswana. Journal of Political Economy 93(5): 901-18.

Mahler, S. J. 1999. Engendering transnational migration: a case study of Salvadorans. American Behavioral Scientist 42(4): 690-719. 
Accepted Manuscript (AM) of King, R., Castaldo, A. and Vullnetari, J. (2011) Gendered relations and filial duties along the Greek-Albanian remittance corridor. Economic Geography 87(4): 393419 [DOI: 10.1111/j.1944-8287.2011.01128.x][accepted 20 March 2011; published November 2011].

Mahler, S. J., and Pessar, P. 2001. Gendered geographies of power: analyzing gender across transnational spaces. Identities 7(4): 441-59.

Markova, E., and Reilly, B. 2006. Bulgarian migrant remittances and legal status: some micro-level evidence from Madrid. Brighton: Sussex Centre for Migration Research working paper 37.

McKay, D. 2005. Reading remittance landscapes: female migration and agricultural transition in the Philippines. Geografisk Tidsskrift 105(1): 8999.

Moreno-Fontes Chammartin, G., and Cantú-Bazaldúa, F. 2003. Identification of potential for increasing employment and productive investment in Albania, Moldova and Ukraine based on remittances. Geneva: ILO, International migration papers 74 .

Morokvasic, M. 1984. Birds of passage are also women. International Migration Review 18(4): 886-907.

Naufal, G. 2007. Who Remits? The Case of Nicaragua. Bonn, Germany: Institute for Study of Labor (IZA), discussion paper 3081.

Nicholson, B. 2004. Migrants as agents of development: Albanian return migrants and micro-enterprise, in New patterns of labour migration in Central and Eastern Europe, ed. D. Pop, 94-110. Cluj Napoca: Public Policy Center.

Nikas, C., and King, R. 2005. Economic growth through remittances: lessons from the Greek experience of the 1960 s applicable to the Albanian case. Journal of Southern Europe and the Balkans 7(2): 235-57.

Nixon, N. 2009. 'You can't eat shame with bread': gender and collective shame in Albanian society. Southeast European and Black Sea Studies 9(1): 105-21.

Nyberg Sørensen, N. 2005. Migrant remittances, development and gender. Copenhagen: Danish Institute for International Studies.

Osaki, K. 1999. Economic interactions of migrants and their households of origin: are women more reliable supporters? Asian and Pacific Migration Journal 8(4): 447-71.

Pessar, P. 1999 Engendering migration studies: the case of new immigrants in the United States. American Behavioral Scientist 42(4): 577-600.

Pessar, P., and Mahler, S. J. 2003. Transnational migration: bringing gender in. International Migration Review 37(3): 812-46. 
Accepted Manuscript (AM) of King, R., Castaldo, A. and Vullnetari, J. (2011) Gendered relations and filial duties along the Greek-Albanian remittance corridor. Economic Geography 87(4): 393419 [DOI: 10.1111/j.1944-8287.2011.01128.x][accepted 20 March 2011; published November 2011].

Phizacklea, A. ed. 1983. One way ticket: migration and female labour. London: Routledge and Kegan Paul.

Pratsinakis, E. 2005. Aspirations and strategies of Albanian immigrants in Thessaloniki. Journal of Southern Europe and the Balkans 7(2): 195-212.

Psimmenos, I., and Kassimati, K. 2003. Immigration control pathways: organisational culture and work values of Greek welfare officers. Journal of Ethnic and Migration Studies 29(2): 337-71.

Rahman, M. M., and Fee, L. K. 2009. Gender and the remittance process: Indonesian domestic workers in Hong Kong, Singapore and Malaysia. Asian Population Studies 5(2): 103-25.

Ramírez, C., Garcia Dominguez, M., and Míguez Morais, J. 2005. Crossing borders: remittances, gender and development. Santo Domingo: UNINSTRAW working paper.

Sassen, S. 2000. Women's burden: counter-geographies of globalization and the feminization of survival. Journal of International Affairs 53(2): 503-24.

Schwandner-Sievers, S. 2006. 'Culture' in court: Albanian migrants and the anthropologist as expert witness, in Applications of anthropology. Professional anthropology in the twenty-first century, ed. S. Pink, 209-32. Oxford: Berghahn.

Semyonov, M., and Gorodzeisky, A. 2005. Labor, migration, remittances and household income: a comparison between Filipino and Filipina overseas workers. International Migration Review 39(1): 45-68.

Shryock, A. J. 1988. Autonomy, entanglement, and the feud: prestige structures and gender values in Highland Albania. Anthropological Quarterly 61(3): $113-18$.

Silvey, R. 2004. Power, difference and mobility: feminist advances in migration studies. Progress in Human Geography 28(4): 490-506.

Smith, E. 2009. 'Gap-fillers' or 'clan-destroyers'? Transnational female solidarity towards kin in the region of Fier. Southeast European and Black Sea Studies 9(4): 555-73.

Tacoli, C. 1999. International migration and the restructuring of gender asymmetries: continuity and change among Filipino labor migrants in Rome. International Migration Review 33(3): 658-82. 
Accepted Manuscript (AM) of King, R., Castaldo, A. and Vullnetari, J. (2011) Gendered relations and filial duties along the Greek-Albanian remittance corridor. Economic Geography 87(4): 393419 [DOI: 10.1111/j.1944-8287.2011.01128.x][accepted 20 March 2011; published November 2011].

Taylor, J. E. 1987. Undocumented Mexico-US migration and the returns to households in rural Mexico. American Journal of Agricultural Economics 69(3): 626-38.

UNDP-Albania. 2008. Partnering for development: UNDP in Albania 2008. Tirana: UNDP Albania.

UNDP. 2009. Human development report 2009. Overcoming barriers: human mobility and development. New York: United Nations Development Programme.

Van Hear, N., and Nyberg Sørensen, N. 2003. The migration-development nexus. Geneva: IOM.

Vanwey, L. 2004. Altruistic and contractual remittances between male and female migrants and households in rural Thailand. Demography 41(4): 739-56.

Vete, M.F. 1995. The determinants of remittances among Tongans in Auckland. Asian and Pacific Migration Journal 4(1): 55-68.

Vullnetari, J. 2007. Albanian migration and development. State-of-the-art review. Amsterdam: IMISCOE working paper 18.

Whitaker, I. 1981. 'A sack for carrying things': the traditional role of women in Northern Albanian society. Anthropological Quarterly 54(2): 146-56.

Wong, M. 2006. The gendered politics of differences in Ghanaian transnational families. Economic Geography 82(4): 355-81.

World Bank. 2011. Migration and remittances factbook 2011. Washington DC: World Bank (2 $2^{\text {nd }}$ edition).

Zezza, A., Carletto, G., and Davis, B. 2005. Moving away from poverty: a spatial analysis of poverty and migration in Albania. Journal of Southern Europe and the Balkans 7(2): 175-94. 


\section{Migration \\ Gender}

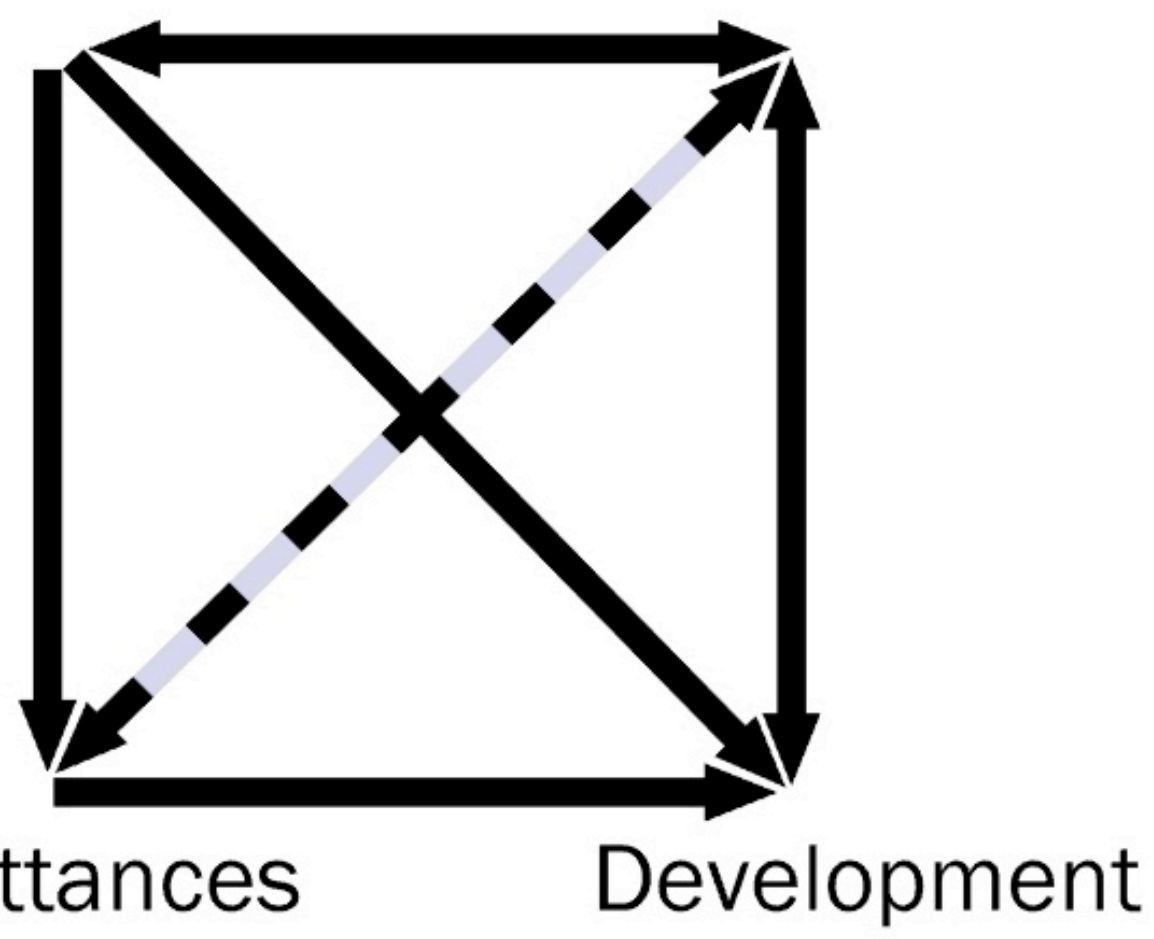

\section{Remittances}

Figure 1. Strength and direction of interlinkages between migration, remittances, development and gender, according to the quantity of existing literatures. 
Accepted Manuscript (AM) of King, R., Castaldo, A. and Vullnetari, J. (2011) Gendered relations and filial duties along the Greek-Albanian remittance corridor. Economic Geography 87(4): 393419 [DOI: 10.1111/j.1944-8287.2011.01128.x][accepted 20 March 2011; published November 2011].

Table 1. Description of variables and summary statistics

\begin{tabular}{|c|c|c|c|}
\hline Variables & $\begin{array}{l}\text { Mean } \\
\text { (st.dev.) } \\
\text { Whole sample }\end{array}$ & $\begin{array}{l}\text { Mean (st.dev.) } \\
\text { Admin is wife }\end{array}$ & $\begin{array}{l}\text { Mean (st.dev.) } \\
\text { Admin is not } \\
\text { wife }\end{array}$ \\
\hline $\begin{array}{l}\text { Log of remittance amount per year (in } \\
\text { euros) }\end{array}$ & $7.53(0.88)$ & $7.88(0.63)$ & $7.39(0.93)$ \\
\hline Occupation of remitter is in construction & 0.60 & 0.47 & 0.65 \\
\hline Occupation of remitter is in agriculture & 0.28 & 0.50 & 0.20 \\
\hline Occupation of remitter is in other sector & 0.12 & 0.03 & 0.15 \\
\hline Age of remitter (in years) & $34.4(9.10)$ & $42.1(8.10)$ & $31.4(7.53)$ \\
\hline Age of remitter squared & $1269(684)$ & $1841(693)$ & $1041(531)$ \\
\hline Age of remitter is between 19 and 25 & 0.17 & 0.02 & 0.24 \\
\hline Age of remitter is between 26 and 35 & 0.42 & 0.20 & 0.51 \\
\hline Age of remitter is between 36 and 45 & 0.29 & 0.45 & 0.21 \\
\hline Age of remitter is $46+$ & 0.12 & 0.33 & 0.04 \\
\hline $\begin{array}{l}\text { Education of remitter is less than } 8 \text { years of } \\
\text { schooling }\end{array}$ & 0.08 & 0.10 & 0.06 \\
\hline $\begin{array}{l}\text { Education of remitter is } 8 \text { years of } \\
\text { schooling }\end{array}$ & 0.64 & 0.64 & 0.65 \\
\hline $\begin{array}{l}\text { Education of remitter is } 9 \text { years of } \\
\text { schooling or more }\end{array}$ & 0.28 & 0.26 & 0.29 \\
\hline Remitter was abroad for 5 years or more & 0.77 & 0.68 & 0.80 \\
\hline $\begin{array}{l}\text { Remitter is married and his wife is in } \\
\text { Greece }\end{array}$ & 0.37 & 0.00 & 0.52 \\
\hline $\begin{array}{l}\text { Remitter is married and his wife is in } \\
\text { Albania with the in-laws }\end{array}$ & 0.19 & 0.29 & 0.15 \\
\hline $\begin{array}{l}\text { Remitter is married and his wife is in } \\
\text { Albania without in-laws }\end{array}$ & 0.20 & 0.71 & 0.00 \\
\hline Remitter is single & 0.24 & 0.00 & 0.33 \\
\hline $\begin{array}{l}\text { Remitter has children in the household in } \\
\text { Albania }\end{array}$ & 0.37 & 0.81 & 0.20 \\
\hline $\begin{array}{l}\text { Household income is low (less than } \\
100, \text { ooo lek }[\$ 1000])\end{array}$ & 0.32 & 0.58 & 0.21 \\
\hline $\begin{array}{l}\text { Household income is medium }(100,000- \\
200,000 \text { lek }[\$ 1000-\$ 2000])\end{array}$ & 0.30 & 0.25 & 0.32 \\
\hline $\begin{array}{l}\text { Household income is high (200,001- } \\
300, \text { ooo lek [\$2001-\$3000]) }\end{array}$ & 0.19 & 0.09 & 0.24 \\
\hline $\begin{array}{l}\text { Household income is very high (more than } \\
300, \text { ooo lek }[\$ 3000] \text { ) }\end{array}$ & 0.19 & 0.08 & 0.23 \\
\hline $\begin{array}{l}\text { The household in Albania is small (1-2 } \\
\text { pers.) }\end{array}$ & 0.43 & 0.14 & 0.54 \\
\hline The household in Albania is average $(3-4)$ & 0.44 & 0.71 & 0.34 \\
\hline The household in Albania is large $\left(5^{+}\right)$ & 0.13 & 0.15 & 0.12 \\
\hline $\begin{array}{l}\text { There are other migrants who remit to the } \\
\text { household }\end{array}$ & 0.18 & 0.09 & 0.21 \\
\hline Remittances are used for savings & 0.24 & 0.24 & 0.24 \\
\hline Remittances are used for pensions & 0.32 & 0.26 & 0.34 \\
\hline Remittances are used for housing & 0.56 & 0.74 & 0.49 \\
\hline $\begin{array}{l}\text { Remittances are used to repay migration } \\
\text { debt }\end{array}$ & 0.12 & 0.21 & 0.08 \\
\hline \# observations & 340 & 97 & 243 \\
\hline
\end{tabular}

Note 1: The mean for dummy variables indicates the proportion of the sample that falls in the relevant group. For example, $60 \%$ of the sample reported that the main remitter is working in the construction sector.

Note 2: Not all the variables shown in Table 1 appear in the final regression results presented in Tables 2 and 3 . 
Table 2. Model 1: Regression analysis of the amount of remittances without variables on use of remittances

\begin{tabular}{|c|c|c|c|}
\hline Variable & $\begin{array}{l}\text { Estimated } \\
\text { OLS } \\
\text { coefficients } \\
\text { (std. errors) - } \\
\text { Whole } \\
\text { sample }\end{array}$ & $\begin{array}{l}\text { Estimated OLS } \\
\text { coefficients } \\
\text { (std. errors) - } \\
\text { Admin is wife }\end{array}$ & $\begin{array}{l}\text { Estimated OLS } \\
\text { coefficients } \\
\text { (std. errors) - } \\
\text { Admin is not } \\
\text { wife }\end{array}$ \\
\hline Occupation of remitter is in agriculture & $\begin{array}{l}-0.30^{* * *} \\
(0.10)\end{array}$ & $\begin{array}{l}-0.61^{* * *} \\
(0.12)\end{array}$ & $\begin{array}{l}-0.13 \\
(0.14)\end{array}$ \\
\hline Age of remitter (in years) & $\begin{array}{l}-0.15^{* * *} \\
(0.04)\end{array}$ & $\begin{array}{l}-0.10 \\
(0.07) \\
\end{array}$ & $\begin{array}{l}-0.14^{* *} \\
(0.05)\end{array}$ \\
\hline Age of remitter squared & $\begin{array}{l}0.002 * * * \\
(0.001)\end{array}$ & $\begin{array}{l}0.001 \\
(0.001)\end{array}$ & $\begin{array}{l}0.002^{* *} \\
(0.001)\end{array}$ \\
\hline $\begin{array}{l}\text { Education of remitter is less than } 8 \\
\text { years of schooling }\end{array}$ & $\begin{array}{l}\text { Reference } \\
\text { category }\end{array}$ & $\begin{array}{l}\text { Reference } \\
\text { category }\end{array}$ & $\begin{array}{l}\text { Reference } \\
\text { category }\end{array}$ \\
\hline $\begin{array}{l}\text { Education of remitter is } 8 \text { years of } \\
\text { schooling }\end{array}$ & $\begin{array}{l}0.57^{* * * *} \\
(0.16)\end{array}$ & $\begin{array}{l}0.39^{*} \\
(0.22)\end{array}$ & $\begin{array}{l}0.69^{* * *} \\
(0.22)\end{array}$ \\
\hline $\begin{array}{l}\text { Education of remitter is } 9 \text { years of } \\
\text { schooling or more }\end{array}$ & $\begin{array}{l}0.58^{* * *} \\
(0.18)\end{array}$ & $\begin{array}{l}0.28 \\
(0.25)\end{array}$ & $\begin{array}{l}0.71^{* * *} \\
(0.24)\end{array}$ \\
\hline $\begin{array}{l}\text { Remitter was abroad for } 5 \text { years or } \\
\text { more }\end{array}$ & $\begin{array}{l}0.42^{* * *} \\
(0.10)\end{array}$ & $\begin{array}{l}0.36^{* * * *} \\
(0.13)\end{array}$ & $\begin{array}{l}0.49^{* * * *} \\
(0.14)\end{array}$ \\
\hline Remitter is single & $\begin{array}{l}0.30^{* *} \\
(0.13)\end{array}$ & Not applicable & $\begin{array}{l}0.36^{* *} \\
(0.15)\end{array}$ \\
\hline $\begin{array}{l}\text { Remitter has children in the household } \\
\text { in Albania }\end{array}$ & $\begin{array}{l}0.68^{* * *} \\
(0.14)\end{array}$ & $\begin{array}{l}0.25 \\
(0.19) \\
\end{array}$ & $\begin{array}{l}0.88^{* * * *} \\
(0.19)\end{array}$ \\
\hline Remittances administrator is the wife & $\begin{array}{l}0.48^{* * *} \\
(0.14)\end{array}$ & Not applicable & Not applicable \\
\hline $\begin{array}{l}\text { Household income is low (less than } \\
100,000 \text { lek }[\$ 1000])\end{array}$ & $\begin{array}{l}-0.42^{* * *} \\
(0.11)\end{array}$ & $\begin{array}{l}0.07 \\
(0.16)\end{array}$ & $\begin{array}{l}-0.58^{* * *} \\
(0.14)\end{array}$ \\
\hline $\begin{array}{l}\text { Household income is medium } \\
(100,000-200,000 \text { lek }[\$ 1000- \\
\$ 2000])\end{array}$ & $\begin{array}{l}-0.29^{* * *} \\
(0.10)\end{array}$ & $\begin{array}{l}0.16 \\
(0.18)\end{array}$ & $\begin{array}{l}-0.37^{* * *} \\
(0.12)\end{array}$ \\
\hline $\begin{array}{l}\text { Household income is high or very high } \\
\text { (more than } 200,000 \text { lek }[\$ 2000] \text { ) }\end{array}$ & $\begin{array}{l}\text { Reference } \\
\text { category }\end{array}$ & $\begin{array}{l}\text { Reference } \\
\text { category }\end{array}$ & $\begin{array}{l}\text { Reference } \\
\text { category }\end{array}$ \\
\hline $\begin{array}{l}\text { The household in Albania is small (1-2 } \\
\text { pers.) }\end{array}$ & $\begin{array}{l}-0.15 \\
(0.11)\end{array}$ & $\begin{array}{l}-0.07 \\
(0.21)\end{array}$ & $\begin{array}{l}-0.11 \\
(0.14)\end{array}$ \\
\hline $\begin{array}{l}\text { The household in Albania is average } \\
(3-4)\end{array}$ & $\begin{array}{l}\text { Reference } \\
\text { category }\end{array}$ & $\begin{array}{l}\text { Reference } \\
\text { category }\end{array}$ & $\begin{array}{l}\text { Reference } \\
\text { category }\end{array}$ \\
\hline The household in Albania is large $\left(5^{+}\right)$ & $\begin{array}{l}0.16 \\
(0.14)\end{array}$ & $\begin{array}{l}0.38^{* * *} \\
(0.17)\end{array}$ & $\begin{array}{l}0.02 \\
(0.19)\end{array}$ \\
\hline Constant & $\begin{array}{l}9.35^{* * *} \\
(0.69)\end{array}$ & $\begin{array}{l}9.12^{* * *} \\
(1.38)\end{array}$ & $\begin{array}{l}8.91^{* * *} \\
(0.94)\end{array}$ \\
\hline \# observations & 340 & 97 & 243 \\
\hline $\begin{array}{l}\text { F statistic: overall significance of the } \\
\text { regression (Model 1) }\end{array}$ & $10.7^{* * *}$ & $4.10^{* * *}$ & $7.45^{* * *}$ \\
\hline R-squared & 0.30 & 0.35 & 0.28 \\
\hline
\end{tabular}

Note: ${ }^{*}$ indicates that the estimated coefficient is significant at $10 \%$ level; ${ }^{* *}$ indicate that the estimated coefficient is significant at $5 \%$ level; $* * *$ indicate that the estimated coefficient is significant at $1 \%$ level. 
Accepted Manuscript (AM) of King, R., Castaldo, A. and Vullnetari, J. (2011) Gendered relations and filial duties along the Greek-Albanian remittance corridor. Economic Geography 87(4): 393419 [DOI: 10.1111/j.1944-8287.2011.01128.x][accepted 20 March 2011; published November 2011].

Table 3. Model 2: Regression analysis of the amount of remittances with variables on use of remittances

\begin{tabular}{|c|c|c|c|}
\hline Variable & $\begin{array}{l}\text { Estimated } \\
\text { OLS } \\
\text { coefficients } \\
\text { (std. errors) - } \\
\text { Whole } \\
\text { sample }\end{array}$ & $\begin{array}{l}\text { Estimated OLS } \\
\text { coefficients } \\
\text { (std. errors) - } \\
\text { Admin is wife }\end{array}$ & $\begin{array}{l}\text { Estimated OLS } \\
\text { coefficients } \\
\text { (std. errors) - } \\
\text { Admin is not } \\
\text { wife }\end{array}$ \\
\hline Occupation of remitter is in agriculture & $\begin{array}{l}-0.17^{*} \\
(0.10)\end{array}$ & $\begin{array}{l}-0.39^{* * *} \\
(0.11)\end{array}$ & $\begin{array}{l}-0.10 \\
(0.13)\end{array}$ \\
\hline Age of remitter (in years) & $\begin{array}{l}-0.12^{* * *} \\
(0.04)\end{array}$ & $\begin{array}{l}-0.08 \\
(0.06)\end{array}$ & $\begin{array}{l}-0.11^{* *} \\
(0.05)\end{array}$ \\
\hline Age of remitter squared & $\begin{array}{l}0.001^{* * *} \\
(0.001)\end{array}$ & $\begin{array}{l}0.001 \\
(0.001)\end{array}$ & $\begin{array}{l}0.001^{*} \\
(0.001)\end{array}$ \\
\hline $\begin{array}{l}\text { Education of remitter is less than } 8 \\
\text { years of schooling }\end{array}$ & $\begin{array}{l}\text { Reference } \\
\text { category }\end{array}$ & $\begin{array}{l}\text { Reference } \\
\text { category }\end{array}$ & $\begin{array}{l}\text { Reference } \\
\text { category }\end{array}$ \\
\hline $\begin{array}{l}\text { Education of remitter is } 8 \text { years of } \\
\text { schooling }\end{array}$ & $\begin{array}{l}0.33^{* *} \\
(0.16)\end{array}$ & $\begin{array}{l}0.05 \\
(0.21)\end{array}$ & $\begin{array}{l}0.51^{* *} \\
(0.21)\end{array}$ \\
\hline $\begin{array}{l}\text { Education of remitter is } 9 \text { years of } \\
\text { schooling or more }\end{array}$ & $\begin{array}{l}0.42^{* *} \\
(0.17)\end{array}$ & $\begin{array}{l}0.10 \\
(0.23)\end{array}$ & $\begin{array}{l}0.61^{* * *} \\
(0.22)\end{array}$ \\
\hline $\begin{array}{l}\text { Remitter was abroad for } 5 \text { years or } \\
\text { more }\end{array}$ & $\begin{array}{l}0.27^{* * *} \\
(0.10)\end{array}$ & $\begin{array}{l}0.14 \\
(0.12)\end{array}$ & $\begin{array}{l}0.36^{* * *} \\
(0.14)\end{array}$ \\
\hline Remitter is single & $\begin{array}{l}0.33^{* * *} \\
(0.12)\end{array}$ & Not applicable & $\begin{array}{l}0.39^{* * *} \\
(0.14)\end{array}$ \\
\hline $\begin{array}{l}\text { Remitter has children in the household } \\
\text { in Albania }\end{array}$ & $\begin{array}{l}0.59^{* * * *} \\
(0.14)\end{array}$ & $\begin{array}{l}0.22 \\
(0.17)\end{array}$ & $\begin{array}{l}0.76^{* * *} \\
(0.18)\end{array}$ \\
\hline Remittances administrator is the wife & $\begin{array}{l}0.45^{* * *} \\
(0.13)\end{array}$ & Not applicable & Not applicable \\
\hline $\begin{array}{l}\text { Household income is low (less than } \\
100,000 \text { lek }[\$ 1000])\end{array}$ & $\begin{array}{l}-0.30^{* * *} \\
(0.10)\end{array}$ & $\begin{array}{l}0.10 \\
(0.15)\end{array}$ & $\begin{array}{l}-0.45^{* * *} \\
(0.13)\end{array}$ \\
\hline $\begin{array}{l}\text { Household income is medium } \\
(100,000-200,000 \text { lek }[\$ 1000- \\
\$ 2000])\end{array}$ & $\begin{array}{l}-0.21^{* *} \\
(0.10)\end{array}$ & $\begin{array}{l}0.16 \\
(0.16)\end{array}$ & $\begin{array}{l}-0.28^{* *} \\
(0.12)\end{array}$ \\
\hline $\begin{array}{l}\text { Household income is high or very high } \\
\text { (more than } 200,000 \text { lek }[\$ 2000] \text { ) }\end{array}$ & $\begin{array}{l}\text { Reference } \\
\text { category }\end{array}$ & $\begin{array}{l}\text { Reference } \\
\text { category }\end{array}$ & $\begin{array}{l}\text { Reference } \\
\text { category }\end{array}$ \\
\hline $\begin{array}{l}\text { The household in Albania is small (1-2 } \\
\text { pers.) }\end{array}$ & $\begin{array}{l}-0.10 \\
(0.10)\end{array}$ & $\begin{array}{l}0.05 \\
(0.19)\end{array}$ & $\begin{array}{l}-0.11 \\
(0.13)\end{array}$ \\
\hline $\begin{array}{l}\text { The household in Albania is average } \\
(3-4)\end{array}$ & $\begin{array}{l}\text { Reference } \\
\text { category }\end{array}$ & $\begin{array}{l}\text { Reference } \\
\text { category }\end{array}$ & $\begin{array}{l}\text { Reference } \\
\text { category }\end{array}$ \\
\hline The household in Albania is large $\left(5^{+}\right)$ & $\begin{array}{l}0.22^{*} \\
(0.13)\end{array}$ & $\begin{array}{l}0.51^{* * *} \\
(0.15)\end{array}$ & $\begin{array}{l}0.08 \\
(0.18)\end{array}$ \\
\hline Remittances are used for savings & $\begin{array}{l}0.51^{* * * *} \\
(0.09)\end{array}$ & $\begin{array}{l}0.50^{* * *} \\
(0.13)\end{array}$ & $\begin{array}{l}0.48^{* * *} \\
(0.12)\end{array}$ \\
\hline Remittances are used for pensions & $\begin{array}{l}0.25^{* * * *} \\
(0.08)\end{array}$ & $\begin{array}{l}-0.08 \\
(0.13)\end{array}$ & $\begin{array}{l}0.36^{* * *} \\
(0.11)\end{array}$ \\
\hline Remittances are used for housing & $\begin{array}{l}0.29^{* * *} \\
(0.08)\end{array}$ & $\begin{array}{l}0.41^{* * *} \\
(0.13)\end{array}$ & $\begin{array}{l}0.30^{* * *} \\
(0.10)\end{array}$ \\
\hline $\begin{array}{l}\text { Remittances are used to repay } \\
\text { migration debt }\end{array}$ & $\begin{array}{l}-0.23^{*} \\
(0.12)\end{array}$ & $\begin{array}{l}-0.27^{*} \\
(0.14)\end{array}$ & $\begin{array}{l}-0.26 \\
(0.18)\end{array}$ \\
\hline Constant & $\begin{array}{l}8.60^{* * *} \\
(0.65)\end{array}$ & $\begin{array}{l}8.71^{* * *} \\
(1.22)\end{array}$ & $\begin{array}{l}8.15^{* * *} \\
(0.90)\end{array}$ \\
\hline \# observations & 340 & 97 & 243 \\
\hline $\begin{array}{l}\text { F statistic: overall significance of the } \\
\text { regression (Model 2) }\end{array}$ & $12.97^{* * *}$ & $5.88^{* * *}$ & $8.81^{* * *}$ \\
\hline R-squared & 0.41 & 0.52 & 0.38 \\
\hline $\begin{array}{l}\text { F statistic: joint significance of } \\
\text { coefficients on variables of remittance } \\
\text { use }\end{array}$ & $14.56^{* * *}$ & $7 \cdot 38^{* * *}$ & $9.56^{* * *}$ \\
\hline
\end{tabular}

